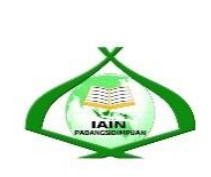

At-Tijaroh : Jurnal Ilmu Manajemen dan Bisnis Islam

Volume 5 Nomor 2 Ed. Juli-Desember 2019: Hal 296-309

p-ISSN : 2356-492x

e-ISSN : 2549-9270

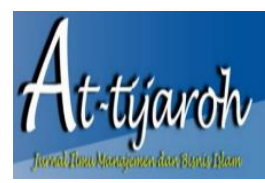

\title{
KONSEP MANAJEMEN SYARIAH DALAM MENGHADAPI \\ TANTANGAN GENERASI MILLENNIAL
}

Fatkhur Rohman Albanjari ${ }^{1}$, Ahmad Iqbal Tanjung ${ }^{2}$

${ }^{1}$ Institut Agama Islam Negeri Tulungagung

${ }_{2}^{2}$ Institut Agama Islam Negeri Padangsidimpuan

${ }^{1} \mathrm{Jl}$. Mayor Sujadi, No. 46 Tulungagung, Jawa Timur

2JL.T Rizal Nurdin No.Km 4 Padang Sidempuan

1fatkhurrohmanalbanjari@gmail.com,

2ibalahamd88@gmail.com

\section{Abstract}

The purpose of this research is to find out how to implement Sharia management on BMT Istiqomah Karangrejo Tulungagung in the challenge of the millennials era. This research uses qualitative research methods which describe real conditions in the field through the observation and interviews. Based on the results of the study, it can be concluded that: 1) the implementation of planning in BMT Istiqomah Karangrejo Tulungagung can already be said either in the field of human resources or planning in the field of finance; 2) Implementation of organizing in BMT Istiqomah Karangrejo is already based on the ability of employees, employees are led to be able to control the Internet and social media in their work; 3) Implementation of employee briefing in BMT Istiqomah Karangrejo Tulungagung is done by providing motivation to always work well to achieve the objectives of the company; 4) Implementation of supervision aims to minimize the misappropriation and lack of good organizational processes that take place; 5) Implementation of evaluation is conducted every one month which is done by manager to all employees, as well as an annual evaluation conducted by BMT Istiqomah Karangrejo Tulungagung by inviting all investors.

Keywords: Sharia management, Millennial Generation, Baitul Maal Wat Tamwil

Tujuan penelitian ini adalah untuk mengetahui bagaimana implementasi manajemen syariah pada BMT Istiqomah Karangrejo Tulungagung dalam mengahadapi tantangan era millennials. Penelitian ini menggunakan metode penelitian kualitatif dimana menggambarkan kondisi riil di lapangan melalui obeservasi dan wawancara. Berdasarkan hasil penelitian, dapat disimpulkan bahwa: 1) Pelaksanaan perencanaan pada BMT Istiqomah Karangrejo Tulungagung sudah dapat dikatakan baik di bidang SDM atau perencanaan di bidang keuangan; 2) Pelaksanaan pengorganisasian pada BMT Istiqomah Karangrejo Tulungagung sudah didasarkan pada kemampuan karyawan, karyawan dituntun untuk bisa mengendalikan internet dan sosial media dalam pekerjaannya; 3) Pelaksanaan pengarahan karyawan pada BMT Istiqomah Karangrejo Tulungagung dilakukan dengan cara memberikan motivasi agar selalu bekerja dengan baik untuk mencapai tujuan perusahaan; 4) Pelaksanaan pengawasan bertujuan untuk meminimalisir adanya penyelewengan dan kurang baiknya proses organisasi yang berlangsung; 5) Pelaksanaan evaluasi dilakukan setiap satu bulan yang dilakukan oleh manager kepada seluruh karyawan, serta evaluasi tahunan yang dilakukan oleh BMT Istiqomah Karangrejo Tulungagung dengan mengundang seluruh penanam saham.

Kata Kunci : Manajemen Syariah, Generasi Millennial, Baitul Maal Wat Tamwil 


\section{7 | Konsep Manajemen Syariah Dalam Menghadapi Tantangan Generasi Millennial}

\section{PENDAHULUAN}

Dalam kehidupan millennials yang semakin maju dan ketatnya persaingan, maka semua pihak dituntut untuk mengatur segala pekerjaan dengan sistematis dengan tujuan agar apa yang telah direncanakan di awal dapat tercapai dengan baik. Begitu juga dalam sebuah perusahaan dituntut untuk bisa mengikuti perkembangan zaman. Semua itu dapat terlaksana dengan baik apabila dalam perusahan menerapkan sebuah manajemen yang baik. Begitu juga dengan perusahaan yang berbasis Islam yang mempunyai visi tidak hanya untuk tujuan duniawi namun juga untuk kemaslahatan ummat, maka harus menerapkan manajemen yang tidak hanya berorientasi pada dunia, tetapi harus menerapkan manajemen yang berorientasi pada Islam dan akhirat.

Manajemen sebagai ilmu (scince) merupakan kumpulan pengetahuan yang telah diorganisasikan secara sistematis dan telah diuji kebenarannya melalui percobaan atau pengamatan dengan cermat dan teliti (Bahrudin, 2013). Manajemen sebagai seni, antara ilmu dan seni saling berkesinambungan, karena seni merupakan sebuah pengetahuan bagaimana mencapai hasil yang diinginkan, hal ini dapat diperoleh dari pengalaman, pengamatan dan pelajaran serta kemampuan untuk menggunakan pengetahuan manajemen (Terry, 2009).

Islam sebagai suatu sistem hidup yang sempurna tentu saja memiliki konsep pemikiran tentang manajemen. Kesalahan kebanyakan dari kaum muslimin dalam memahami konsep manajemen dari sudut pandang Islam adalah karena masih mencampuradukan antara ilmu manajemen yang bersifat teknis (uslub) dengan manajemen sebagai aktivitas. Kerancuan ini akan mengakibatkan kaum muslimin susah membedakan mana yang boleh diambil dari perkembangan ilmu manajemen saat ini dan mana yang tidak.

Manajemen syariah adalah suatu pengelolaan untuk memperoleh hasil optimal yang bermuara pada pencarian keridhaan Allah SWT (Bahruddin, 2013). Oleh sebab itu maka segala sesuatu langkah yang diambil dalam menjalankan manajemen tersebut harus berdasarkan aturan-aturan-aturan Allah SWT. Aturan-aturan itu tertuang dalam al-Qur'an, al-Hadist dan beberapa contoh yang dilakukan oleh para sahabat.

Berdasarkan prinsip atau kaidah dan teknik manajemen yang ada relevansinya dengan al-Qur'an atau al-Hadist antara lain prinsip amar ma'ruf nahi munkar, kewajiban menegakkan keadilan, kewajiban menegakkan kebenaran, dan kewajiban menyampaikan 
amanah (Muhammad, 2011). Sebagai perbankan yang berbasis syariah, seharusnya semua elemen sudah menerapkan kegiatan manajemen sesuai syariat Islam. Dalam Islam, manajemen dipandang sebagai perwujudan amal shaleh yang harus bertitik tolak dari niat baik. Niat baik tersebut akan memunculkan motivasi untuk mencapai hasil yang baik demi kesejahteraan bersama. Paling tidak, ada empat landasan untuk mengembangkan manajemen menurut pandangan Islam, yaitu kebenaran, kejujuran, keterbukaan, dan keahlian. Seorang manajer harus memiliki empat sifat utama itu agar manajemen yang dijalankannya mendapatkan hasil yang maksimal (Kamaluddin, 2009).

Dewasa ini, semua lembaga keuangan mikro syariah dituntut untuk bisa menguasai perkembangan teknologi. Masih banyak lembaga keuangan syariah yang mempertahankan generasi X (yakni generasi dengan tahun kelahiran 1960 sampai 1980) dalam pengelolaannya. Sesuai perkembangan zaman, genarasi X harus mampu untuk bersaing dengan generasi $\mathrm{Y}$ (generasi dengan tahun kelahiran 1981 sampai 1995) dan Z (generasi dengan tahun kelahiran 1996 sampai 2012) dalam mengelola lembaga keuangan mikro syariah. Demikian halnya dengan kondisi pada BMT Istiqomah Karangrejo Tulungagung yang masih mempertahankan generasi $\mathrm{X}$ dalam kegiatan operasionalnya, karena lebih memiliki pengalaman dan pengetahuan ketimbang generasi $\mathrm{Y}$ dan $\mathrm{Z}$.

Baitul Maal Wat Tamwil (BMT) ini merupakan sebuah institusi lembaga keuangan yang menjalan dua bidang kegiatan, yakni baitul maal dan baitul tamwil. Pada praktiknya, baitul maal merupakan kegiatan yang bergerak dalam bidang sosial dakwah seperti; zakat, infaq, sedekah dan wakaf. Sedangkan baitul tamwil merupakan kegiatan yang bergerak dalam bidang profit oriented, seperti pembiayaan dan simpanan/tabungan.

BMT Istiqomah merupakan lembaga keuangan mikro syariah yang didirikan oleh Kelompok Swadaya Masyarakat (KSM) sebagai Lembaga Ekonomi Rakyat (LER). BMT Istiqomah beralamatkan di Jl. Dahlia, Karangrejo, Tulungagung. BMT Istiqomah Karangrejo didirikan pada tanggal 3 Maret 2001 yang dipelopori oleh 36 orang pendiri. Pada tanggal 4 Juni 2001 BMT Istiqomah Karangrejo diresmikan operasionalnya oleh Direktur PINBUK Tulungagung dengan sertifikat Binaan Pusat Inkubasi Bisnis Usaha Kecil (PINBUK) tulungagung Nomor: 00101/52000/PINBUK/VI/2001 (Buku RAT BMT Istiqomah, 2018). 


\section{9 | Konsep Manajemen Syariah Dalam Menghadapi Tantangan Generasi Millennial}

Berdasarkan pendahuluan di atas, maka masalah penelitian ini difokuskan pada bagaimana penerapan manajemen syariah di BMT Istiqomah Karangrejo Tulungagung dalam menghadapi tantangan generasi millennial, apakah sudah menerapkan konsep manajemen syariah yang dibutuhkan oleh perkembangan zaman ataukah tidak.

Konsep manajemen telah berkembang sejak berabad-abad yang lalu, apabila dikaitkan dalam konteks upaya kerjasama dalam suatu kelompok masyarakat untuk mencapai suatu tujuan tertentu (Rivai, 2010). Manajemen berasal dari kata "to manage” yang berarti mengatur (Hasibuan, 2013). Manajemen ialah sebuah ilmu seni mengatur proses pemanfaatan sumber daya manusia dan sumber-sumber lainnya secara efektif dan efisien untuk mencapai tujuan tertentu. Istilah manajemen berhubungan dengan usaha untuk tujuan tertentu dengan jalan menggunakan sumber-sumber daya yang tersedia dalam organisasi dengan cara yang sebaik mungkin. Tercapainya tujuan organisasi baik tujuan ekonomi, sosial, maupun politik, sebagian besar tergantung kepada kemampuan para manajer dalam organisasi yang bersangkutan. Manajemen akan memberikan efektifitas pada manusia (Aanoraga, 2004).

Manajemen syariah merupakan suatu pengelolaan untuk memperoleh hasil optimal yang bermuara pada pencarian keridhaan Allah SWT. Oleh sebab itu, segala sesuatu langkah yang diambil dalam menjalankan manajemen tersebut harus berdasarkan aturan-aturan Allah SWT. Aturan-aturan itu tertuang dalam al-Qur'an maupun al- Hadist (Badrudin, 2003).

Al-Qur'an juga terdaat penjelasan mengenai manajemen, yaitu pada QS Ash-Shaff ayat 4, sebagai berikut:

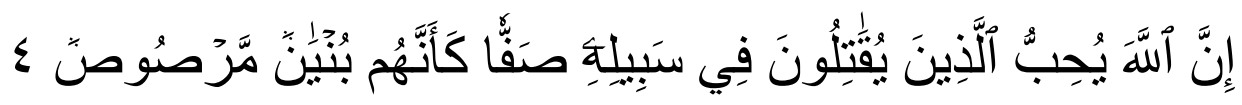

Artinya "Sesungguhnya Allah mencintai orang-orang yang berperang dijalan-Nya dalam barisan yang teratur, mereka seakan-akan seperti suatu bangunan yang tersusun kokoh.”

Diantara karakteristik yang membedakan teori manajemen dalam Islam dengan teori lain adalah fokus dan konsen teori Islam terhadap segala variabel yang berpengaruh terhadap aktivitas manajemen dalam dan luar organisasi, dan hubungan perilaku individu terhadap faktor-faktor sosial yang berpengaruh. Teori Islam memberikan injeksi moral dalam manajemen, yakni mengatur bagaimana seharusnya individu berperilaku. Tidak ada 
manajemen dalam Islam kecuali ada nilai atau etika yang melingkupinya, sebagaimana tidak mungkin membangun masyarakat muslim tanpa didasari dengan akhlak.

Manajemen Islami memandang manajemen sebagai objek yang sangat berbeda dibanding konvensional. Dalam manajemen konvensional manusia dipandang sebagai makhluk ekonomi, sedangkan dalam Islam manusia merupakan makhluk spiritual, yang mengakui kebutuhan baik material (ekonomi) maupun Immaterial (Kamaluddin, 2009).

Arah pekerjaan yang jelas, landasan yang mantap, dan cara-cara mendapatkannya yang transparan merupakan amal perbuatan yang dicintai Allah SWT. Sebenarnya manajemen dalam arti mengatur segala sesuatu agar dilakukan dengan baik, tepat, dan tuntas merupakan hal yang disyariatkan dalam ajaran Islam (Hafiduddin dan Tanjung, 2003).

BMT merupakan kependekan dari Baitul Maal Wat Tamwil secara harfiyah atau lughowi baitul maal berarti rumah dana dan baitul tamwil berarti rumah usaha. Baitul maal dikembangkan berdasarkan perkembangannya, yakni dari masa Nabi sampai abad pertengahan perkembangan Islam. Dimana baitul maal berfungsi untuk mengumpulkan sekaligus mentasyarufkan dana sosial. Sedangkan baitul tamwil merupakan lembaga bisnis bermotif laba (Ridwan, 2004).

Baitul Maal Wat Tamwil (BMT) atau Balai Usaha Mandiri Terpadu merupakan lembaga keuangan mikro yang dioperasikan dengan prinsip bagi hasil tanpa bunga. BMT menumbuh kembangkan usaha mikro dalam rangka mengangkat derajat dan martabat serta membela kepentingan kaum fakir miskin. Fakir miskin diberikan modal awal dari tokoh-tokoh masyarakat setempat dengan berlandasan pada sistem ekonomi yang salam: keselamatan, keadilan, kedamaian, dan kesejahteraan.

Sebagai lembaga bisnis, BMT lebih mengembangkan usahanya pada sektor keuangan, yakni simpan pinjam. Usaha ini seperti usaha perbankan yakni menghimpun dana anggota dan calon anggota (nasabah) serta menyalurkannya pada sektor ekonomi yang halal dan menguntungkan. Namun demikian, terbuka luas bagi BMT untuk mengembangkan lahan bisnisnya pada sektor riil maupun pada sektor keuangan.

Menurut Manheim dalam buku statistik gender tematik profil generasi milenial Indonesia, generasi adalah suatu konstruksi sosial yang di dalamnya terdapat sekelompok orang yang memiliki kesamaan umur dan pengalaman historis yang sama (Kementerian 


\section{1 | Konsep Manajemen Syariah Dalam Menghadapi Tantangan Generasi Millennial}

Pemberberdayaan Perempuan dan Perlindungan Anak, 2018). Seorang individu yang menjadi bagian dari satu generasi ialah mereka yang memiliki kesamaan tahun lahir dalam rentang waktu 20 tahun. Mereka juga berada dalam dimensi sosial dan dimensi sejarah yang sama. Definisi tersebut secara spesifik juga dikemukakan oleh Ryder (1965) yang mengatakan bahwa generasi merupakan sekelompok individu yang mengalami peristiwa-peristiwa yang sama dalam kurun waktu yang sama pula.

Terdapat 6 pendapat yang berbeda mengenai angka kelahiran generasi millennials ini. Istilah dalam generasi milenial juga berbeda antar peneliti. Menurut Tapscott (1998) generasi milenial dengan istilah Digital Generation yang lahir antara tahun 1976 sampai dengan 2000. Kemudian Zemke et al (2000) menyebut generasi milenial dengan istilah Nexters yang lahir tahun 1980 sampai dengan 1999. Oblinger (2005) menyebut generasi milenial dengan istilah Generasi Y/NetGen, lahir antara tahun 1981 sampai dengan 1995. Terakhir Howe dan Strauss, Lancaster dan Stillman (2002), serta Martin dan Tulgan (2002) menyebut dengan istilah Generasi Milenial/Generasi Y/Milenial yang dikenal sampai sekarang, meskipun rentang tahun kelahirannya masing-masing berbeda.

Sedangkan generasi sebelum millennials yakni Generasi X yang menurut pendapat para peneliti lahir pada rentang tahun 1960-1980. Pada generasi X ini cenderung suka akan risiko dan pengambilan keputusan yang matang akibat dari pola asuh dari generasi sebelumnya atau istilah lain menyebutnya dengan baby boomers. Sehingga nilai-nilai pengajaran dari generasi baby boom masih melekat dalam generasi X ini. Sedangkan generasi baby boom yaitu generasi yang lahir pada rentang tahun 1946 sampai dengan 1960. Generasi ini terlahir saat masa perang dunia kedua (PD II) telah berakhir sehingga perlu penataan ulang kehidupan. Disebut dengan generasi Baby Boom karena di masa tersebutlah kelahiran bayi sangat tinggi.

Untuk generasi setelah generasi millennials terdapat pula generasi Z. Generasi Z ini lahir pada rentang tahun 2001 sampai dengan 2010. Generasi Z merupakan peralihan dari generasi millennials pada saat teknologi sedang berkembang pesat. Generasi Z ini sudah mengenal dan berpengalaman dengan gadget, smartphone, dan kecanggihan teknologi lainnya ketika usia mereka masih dini. Hal ini memunculkan pendapat bahwa generasi Z ini merupakan generasi yang serba instan (Kementerian Pemberberdayaan Perempuan dan Perlindungan Anak, 
2018). Berdasarkan penjelasan di atas, tujuan penelitian ini adalah untuk mengetahui konsep manajemen syariah dalam menghadapi tantangan generasi millennial.

\section{METODE PENELITIAN}

Metode yang digunakan dalam penelitian ini adalah metode penelitian kualitatif. Penelitian kualitatif adalah penelitian yang bermaksud untuk memahami fenomena tentang apa yang dialami oleh subjek penelitian misalnya perilaku, persepsi, motivasi dan tindakan secara holistik dan dengan cara deskripsi dalam bentuk kata-kata dan bahasa, pada suatu konteks khusus yang alamiah dan dengan memanfaatkan berbagai metode alamiah (Moleong, 2007).

Penelitian ini bertujuan untuk memperoleh gambaran seutuhnya mengenai suatu hal. Penelitian ini berhubungan dengan ide, persepsi dan pendapat yang semuanya tidak dapat diukur dengan angka.

Penelitian kualitatif instrumennya adalah peneliti itu sendiri. Menjadi instrumen, maka peneliti harus memiliki bekal teori dan wawasan luas, sehingga mampu bertanya, menganalisis, memotret, dan mengkonstruksi situasi sosial yang diteliti menjadi lebih jelas dan bermakna. Penelitian ini merupakan penelitian deskriptif kualitatif (Sugiono, 2013). Jadi, penelitian ini difokuskan untuk meneliti pada BMT Istiqomah Karangrejo Tulungagung melalui sistem atau metode penelitian kualitatif dengan teknik observasi langsung ke lembaganya dan wawancara pada informan secara mendalam.

\section{HASIL DAN PEMBAHASAN}

Proses-proses manajemen syariah yang diterapkan pada BMT Istiqomah Karangrejo Tulungagung terdiri dari perencanaan (planning), pengorganisasian (organizing), pengarahan (actuating), pengontrolan (controlling), dan evaluasi (evaluating) yang bertumpu pada prinsip syariah. Proses-proses manajemen tersebut dipaparkan berikut ini.

\section{Perencanaan (planning)}

Perencanaan adalah proses penentuan tujuan atau sasaran yang hendak dicapai dan menetapkan jalan dan sumber yang diperlukan untuk mencapai tujuan seefektif dan seefisien 


\section{3 | Konsep Manajemen Syariah Dalam Menghadapi Tantangan Generasi Millennial}

mungkin. Pada dasarnya merencanakan adalah kegiatan yang hendak dilakukan di masa depan. Kegiatan ini dimaksudkan untuk mengatur berbagai sumber daya agar hasil yang dicapai sesuai yang diharapkan. Ada tiga kegiatan dalam setiap perencaaan, diantaranya: 1) Perumusan tujuan yang ingin dicapai; 2) Pemilihan program untuk mencapai tujuan; 3) Identifikasi dan pengerahan sumber yang jumlahnya terbatas (Fatah, 2004).

Pada BMT Istiqomah Karangrejo Tulungagung memiliki dua perencanaan kegiatan dalam mengahadapi tantangan generasi millennials, yakni perencanaan bidang sumber daya manusia (SDM) dan perencanaan bidang:

\section{Perencanaan di Bidang Sumber Daya Manusia (SDM)}

Perencanaan ini meliputi bagaimana cara mendapatkan karyawan yang memiliki sifat yang kafa'ah (ahli di bidangnya), amanah (dapat dipercaya) dan memiliki semangat/etos kerja yang tinggi. Pada hal ini, BMT Istiqomah sudah dapat dikatakan baik dalam proses seleksi karyawan. 70\% karyawan BMT Istiqomah Karangrejo Tulungagung merupakan lulusan pondok pesantren yang menempuh studi lanjut di Institut Agama Islam Negeri (IAIN) Tulungagung, sehingga hal tersebut menjadi nilai tambah BMT Istiqomah Karangrejo Tulungagung. Dalam praktinya karyawan BMT Istiqomah juga dituntut untuk bisa bekerja dengan menggunakan internet. Pelatihan rutin dilakukan oleh karyawan guna manambah pengetahuan dan perkembangan lembaga keuangan.

\section{Perencanaan di Bidang Keuangan}

Dalam hal keuangan perusahaan, BMT Istiqomah awalnya hanya memiliki modal 15 juta, seiring berjalannya waktu mendapat dukungan dan bantuan dari pihak kontraktor yang berdomisili di Kecamatan Karangrejo, sehingga modal yang terkumpul menjadi 400 juta, dan pada saat ini modal seluruhnya mencapai 25 milyar, dengan aset tetap sekitar 4,8 milyar. Dalam pengelolaannya tersebut tentunya pihak BMT Istiqomah harus bekerja keras, perkembangan penggunaan aplikasi core banking system juga terus dikembangkan guna mempermudah kegiatan transaksi keuangannya. Akan tetapi kelemahan dalam lembaga ini masih belum menggunakan m-banking dalam proses transaksi diluar Tulungagung. 
Kelemahan tersebut akan terus dikurangi dengan merekrut karyawan baru yang pandai dalam bertransaksi dan aplikasi manajemen keuangan dengan internet

\section{Pengorganisasian (Organizing)}

Pengorganisasian adalah suatu proses pengaturan dan pengalokasian kerja, wewenang, dan sumber daya di kalangan anggota sehingga mereka dapat mencapai tujuan organisasi secara efisien (Danim dan Suparno, 2009).

Meliputi kegiatan-kegiatan membentuk atau mengadakan struktur organisasi baru untuk menghasilkan produk baru; dan menetapkan garis hubungan kerja antara struktur yang ada dengan struktur baru, merumuskan komunikasi dan hubungan-hubungan, menciptakan deskripsi kedudukan dan menyusun kualifikasi tiap kedudukan yang menunjuk apakah rencana dapat dilaksanakan oleh organisasi yang ada atau diperlukan orang lain yang mempunyai keterampilan khusus (Danim dan Suparno, 2009).

Di BMT Istiqomah Karangrejo Tulungagung itu dalam hal pengorganisasian sudah dapat dikatakan baik, artinya penempatan posisi jabatan karyawan sudah disesuaikan dengan kemampuan yang mereka miliki dan tentunya penentuan ini sudah berdasarkan seleksi. Terdapat pula Dewan Pengawas Organisasi, dewan pengawas tersebut dibagi menjadi 2: Dewan Pengawas Keuangan dan Dewan Pengawas Kesyariahan. Dan disini mereka melakukan pertemuan berkala dengan internal pengawas, pengawas dengan pengurus, dan melibatkan karyawan bila memang diperlukan. Dalam metode kesyariahan ada hal tentang waqiiah, yakni masalah-masalah yang sering berkembang dan diselesaikan dengan pendekatan kesyariahan dan diistilahkan dengan bahtsul masail (sebuah forum diskusi antar ahli keilmuan Islam utamanya fiqih di lingkungan sekitar).

Selain itu juga, pembahasan juga dilakukan untuk perkembangan bisnis lembaga keuangan. Perkembangan untuk terus bisa bersaing dengan lembaga keuangan sekitar dalam menjalankan operasionalnya. Kemudahan, kenyamanan dan kepercayaan kepada nasabah terus ditingkatkan untuk menjalin hubungan yang erat. 


\section{5 | Konsep Manajemen Syariah Dalam Menghadapi Tantangan Generasi Millennial}

\section{Pengarahan (actuating)}

Dari seluruh rangkaian proses manajemen, pelaksanaan (actuating) merupakan fungsi manajemen yang paling utama. Dalam fungsi perencanaan dan pengorganisasian lebih banyak berhubungan dengan aspek-aspek abstrak proses manajemen, sedangkan fungsi actuating justru lebih menekankan pada kegiatan yang berhubungan langsung dengan orangorang dalam organisasi.

Hal yang penting untuk diperhatikan dalam pelaksanan (actuating) ini adalah bahwa seorang karyawan akan termotivasi untuk mengerjakan sesuatu jika : (1) merasa yakin akan mampu mengerjakan, (2) yakin bahwa pekerjaan tersebut memberikan manfaat bagi dirinya, (3) tidak sedang dibebani oleh problem pribadi atau tugas lain yang lebih penting, atau mendesak, (4) tugas tersebut merupakan kepercayaan bagi yang bersangkutan dan (5) hubungan antarteman dalam organisasi tersebut harmonis (Terry, 2000).

Pada BMT Istiqomah Karangrejo Tulungagung, seorang manajer sebenarnya memiliki kedudukan yang sama dengan karyawan lain yang menjunjung tinggi akhlaqul karimah, amanah dan menjunjung nilai kesyariahan di bidang ekonomi. Tetapi seorang manajer mempunyai tugas lebih yaitu untuk memimpin dan mengkoordinir semua karyawan. Pimpinan BMT Istiqomah bertanggung jawab atas SDM dan Keuangan lembaga.

Menurut manajer BMT Istiqomah Karangrejo Tulungagung, sebenarnya semua karyawan mudah diarahkan dan dimotivasi agar menjadi SDM yang berkualitas di bidangnya. SDM diberikan wewenang untuk menjaga nama baik lembaga dan agama. Akan tetapi masih banyak SDM yang memanfaatkan jabatan untuk kepentingan pribadi. Faktor ketidakberhasilan menjalankan lembaga keuangan seperti itu adalah karena internal yang kurang baik. Maka dari itu manajer BMT Istiqomah selalu berpesan kepada seluruh karyawan agar benar-benar menjaga amanah.

\section{Pengawasan (controling)}

Pengawasan dapat di definiskan sebagai proses untuk menjamin bahwa tujuan-tujuan organisasi dan manajemen dapat tercapai. Ini berkenaan dengan cara-cara membuat kegiatan-kegiatan sesuai yang direncanakan. Pengertian ini menunjukkan adanya hubungan yang sangat erat antara perencanaan dan pengawasan (Yahya, 2006). 
Pegawasan merupakan fungsi dalam manajemen fungsional yang harus dilaksanakan oleh setiap pimpinan semua unit/satuan kerja terhadap pelaksanaan pekerjaan atau pegawai yang melaksanakan sesuai dengan tugas pokoknya masing-masing. Dengan demikian, pengawasan oleh pimpinan khusunya yang berupa pengawasan melekat (built in control), merupakan kegiatan manajerial yang dilakukan dengan maksud agar tidak terjadi penyimpangan dalam melaksanakan pekerjaan. Suatu penyimpangan atau kesalahan terjadi atau tidak selama dalam pelaksanaan pekerjaan tergantung pada tingkat kemampuan dan keterampilan pegawai.

Para pegawai yang selalu mendapat pengarahan atau bimbingan dari atasan, cenderung melakukan kesalahan atau penyimpangan yang lebih sedikit dibandingkan dengan pegawai yang tidak memperoleh bimbingan (Kadarisman, 2013).

Agar pengawasan efektif, maka para manajer harus menghayati reaksi manusia terhadap sistem pengawasan. Manusia tidak begitu saja menerima pengawasan yang dilakukan manajer. Reakasinya bisa bermacam-macam. Menolak sama sekali pengawasan terhadapnya, mempertahankan diri dari sistem pengawasan yang diterapkan padanya dan membela kinerjanya dan menolak sasaran kinerja yang tersirat dan tersurat pada tujuan. Hal ini makin jelas bila sumber daya terbatas dan situasi penuh tekanan. Dalam situasi seperti ini orang cenderung untuk mempertahankan hasil kerjanya yang dibatasi oleh kendala sehingga pengawasan biasanya tidak dikendaki.

Pengawasan akan berlangsung dengan efektif apabila memiliki berbagai ciri berikut ini (Siagian, 2005) yaitu pengawasan harus merefleksikan sifat dari berbagai kegiatan yang diselenggarakan, pengawasan harus segera memberikan petunjuk tentang kemungkinan adanya deviasi dari rencana, pengawasan harus menunjukkan pengecualian pada titik-titik strategis tertentu, objektivitas dalam melakukan pengawasan, keluwesan pengawasan, pengawasan harus memperhitungkan pola dasar organisasi, efisiensi pelaksanaan pengawasan.

Pada BMT Istiqomah Karangrejo Tulungagung pengawasan karyawan rutin dilakukan. Pengawasan tersebut meliputi bagaimana target pendapatan, target pengembangan baik dari sisi pendapatan dan kepercayaan nasabah untuk pembiayaan dan bagaimana hal tersebut 


\section{7 | Konsep Manajemen Syariah Dalam Menghadapi Tantangan Generasi Millennial}

diselaraskan dengan kondisi riil yang ada. Karena BMT Istiqomah memegang label syariah, tentunya berbeda dengan lembaga keuangan yang tidak memegang label kesyariahan.

Sebagai contoh misalnya mengenai pemberian atau hadiah dari nasabah. Seorang karyawan disini harus pandai-pandai menyikapi apa maksud dari pemberian tersebut, apakah itu merupakan sejenis suap untuk agar dipermudah pencairan dana. Hal ini tidak diperbolehkan. Jadi evaluasi bagaimana baik dari lingkup pimpinan dan karyawan selalu dilakukan, kemudian berdasarkan hasil lapangan dan berdasarkan dari permasalahan yang disampaikan yang kemudian dibahas setiap awal bulan sebelum mengkoreksi bulan kemarin dan proyeksi kedepan.

Untuk menangani jika ada karyawan yang menyeleweng atau biasanya menerima pemberian dari nasabah, maka karyawan tersebut akan dipanggil oleh manajer dan harus menjelaskan apa maksud dari pemberian tersebut. Jika memang benar adanya maksud lain dari pemberian tersebut maka karyawan tersebut akan dibina agar tidak mengulangi kesalahannya selama kesalahan tersebut masih bisa ditolerir.

\section{Evaluasi (evaluating)}

Evaluasi sangat dibutuhkan dalam berbagai kegiatan kehidupan manusia sehari-hari, karena disadari atau tidak, sebenarnya evaluasi sudah sering dilakukan, baik untuk diri sendiri maupun kegiatan sosial lainnya. Hal ini dapat dilihat mulai dari berpakaian, seteklah berpakaian ia berdiri dihadapan kaca apakah penampilannya wajar atau belum.

Dalam ekonomi Islam evaluasi merupakan salah satu komponen dari sistem yang harus dilakukan secara sistematis dan terencana sebagai alat untuk mengukur keberhasilan atau target yang akan dicapai dalam proses pendidikan Islam dan proses pembelajaran (Ramayulis, 2010). Dengan demikian evaluasi bukan sekedar menilai suatu aktivitas secara spontan dan insidental, melainkan merupakan kegiatan untuk menilai sesuatu secara terencana, sistematik, dan berdasarkan atas tujuan yang jelas (Ramayulis, 2010).

Dengan mendasarkan pada pengertian di atas, maka dapat dikemukakan bahwa evaluasi adalah suatu proses menentukan nilai seseorang dengan menggunakan patokanpatokan tertentu untuk mencapai tujuan. Sementara itu, evaluasi proses produksi adalah suatu proses menentukan nilai proses produksi dengan menggunakan patokan-patokan 
tertentu agar mencapai tujuan pengajaran yang telah ditentukan sebelumnya (Siregar dan Nara, 2011).

Evaluasi dapat digunakan untuk menyusun gradiasi kemampuan karyawan, sehingga ada penanda simbolik yang dilaporkan kepada semua pihak. Evaluasi dilaksanakan secara komprehensif, obyektif, kooperatif, dan efektif. Evaluasi dilaksanakan berpedoman pada tujuan (Soetopo, 2005).

Pada BMT Istiqomah Karangrejo Tulungagung, evaluasi dilakukan setiap satu bulan sekali. Evaluasi difokuskan pada bagimana kinerja karyawan, bagaimana proses-proses manajemen berlangsung. Apakah sudah maksimal atau belum. Jika masih ada yang belum maksimal, maka akan di analisis dimana letak kesalahan atau masalah yang ada.

Evaluasi kerja juga dilakukan oleh BMT Istiqomah Karangrejo Tulungagung pada setiap tahunnya yakni Rapat Anggota Tahunan (RAT). RAT dilaksanakan oleh pendiri, pemegang saham, dan karyawan guna menetapkan kebijakan kedepannya lembaga keuangan ini. Penetapan kebijakan didasarkan pada kinerja tahun-tahun sebelumnya.

\section{KESIMPULAN}

Terdapat 2 rencana kerja dalam BMT Istiqomah Karangrejo Tulungagung, yakni Perencanaan SDM dan perencanaan keuangan. Dalam hal perencanaan khususnya pada bidang Sumber Daya Manusia (SDM), BMT Istiqomah Karangrejo Tulungagung memilih karyawan lulusan pondok pesantren yang melanjutkan studi di IAIN Tulungagung dan untuk perencanaan keuangan, BMT Istiqomah Karangrejo Tulungagung bekerja sama dengan para kontraktor di Kecamatan Karangrejo dan menggunakan internet dalam proses pengelolaan keuangannya. Semua karyawan mudah diarahkan dan dimotivasi agar menjadi SDM yang berkualitas di bidangnya. Akan tetapi masih banyak karyawan yang menggunakan jabatannya untuk kepentingan pribadinya. Faktor ketidakberhasilan menjalankan lembaga keuangan seperti itu adalah karena internal yang kurang baik. Pada BMT Istiqomah Karangrejo Tulungagung pengawasan karyawan rutin dilakukan. Pada BMT Istiqomah Karangrejo Tulungagung, evaluasi dilakukan setiap satu bulan sekali. Evaluasi difokuskan pada bagimana kinerja karyawan, bagaimana proses-proses manajemen berlangsung. Penerapan manajemen berdasarkan prinsip syariah di BMT Istiqomah Karangrejo Tulungagung masih belum 


\section{9 | Konsep Manajemen Syariah Dalam Menghadapi Tantangan Generasi Millennial}

maksimal. Masih terdapat kendala dalam mengelola lembaga keuangan yang ada. Minimnya anggaran biaya untuk perkembangan usaha menjadi kendala. Kecanggihan alat teknologi transaksi juga belum sepenuhnya digunakan oleh BMT Istiqomah Karangrejo untuk menjawab tantangan global era millennials ini. Mereka percaya, lambat laun BMT Istiqomah Karangrejo Tulungagung akan menjadi lembaga keuangan syariah yang amanah, dan konsisten untuk mensyiarkan Islam dengan menggunakan teknologi guna menarik minat millennials.

\section{DAFTAR PUSTAKA}

Ahyari, Agus. 2002. Manajemen Produksi Perencanaan Sistem Produksi. Yogyakarta: BPFEYogyakarta

Anoraga, Pandji. 2004. Manajemen Bisnis. Jakarta: PT. Rineka Cipta

Badrudin. 2013. Dasar-Dasar Manajemen. Bandung: Alfabeta

Hafidhuddin, Didin dan Hendri Tanjung. 2003. Manajemen Syariah Dalam Praktek. Jakarta: Gema Insani

Hasibuan, Malayu S.P. 2013. Manajemen Sumber Daya Manusia. Jakarta: PT. Bumi Aksara

Kamaluddin, Undang Ahmad. 2009. Etika Manajemen Islam. Bandung: Pustaka Setia

Kementerian Pemberdayaan Perempuan dan Perlindungan Anak. 2018. Statistik Gender Tematik; Profil Generasi Milenial Indonesia. Jakaarta: KPPPA

Moloeng , Lexy J. 2007. Metode Penelitian Kualitatif. Bandung : Remaja Rodakarya

Ramayulis. 2010. Ilmu Pendidikan Islam. Jakarta: Kalam Mulia

Ridwan, Muhammad. 2004. manajemen Baitul Maal Wa Tamwil. Yogyakarta: UII Press

Rivai, Veitzal, Arviyan Arifin. 2010. Islamic Banking. Jakarta: Bumi Aksara

Sari, Irine Diana. 2008. Manajemen. Yogyakarta: Mitra Cendikia

Siregar, Eveline dan Hartini Nara. 2011. Teori Belajar dan Pembelajaran. Bogor: Ghalia Indonesia

Soetopo, Hendyat. 2005. Pendidikan dan Pembelajaran (Teori, Permasalahan dan Praktek). Malang: UMM Press

Sugiyono. 2013. Metodelogi Penelitian Kuantitatif, Kualitatif dan R\&D. Bandung : Alfabeta

Sulaiman, Abu Kasim bn Ahmad Tabrani. Al-Mu’jam Al Wusta. Kairo: Dar Harmin, 1415

Terry,G.R dan L.W Rue. 2009. Dasar-Dasar Manajemen. Jakarta: PT. Bumi Aksara 